\title{
The perception of religious institutions on the freedom of expression and the broadcasting proclamation
}

\author{
Gebru Kahsay Kiflu \\ English language and literature Department, College of Social Science and Humanities, Adigrat University, P.Box:50, Adigrat, Ethiopia
}

Email address:

ghiwot2121@gmail.com

To cite this article:

Gebru Kahsay Kiflu. The Perception of Religious Institutions on the Freedom of Expression and the Broadcasting Proclamation. Humanities and Social Sciences. Vol. 3, No. 1, 2015, pp. 1-17. doi: 10.11648/j.hss.20150301.11

\begin{abstract}
This study investigated the perception of religious organizations on the freedom of expression - Article 29 (2) and the broadcasting proclamation No. 533 Article 23/2007 in focus. The researcher employed qualitative methodology with individual in-depth interviews and focus group discussions as data gathering tools. The theoretical framework employed was political economy theory of mass communication. Despite the fact that the Freedom of the Press has been granted as per Article 29 sub article 2 of the Federal Democratic Republic of Ethiopia, the Ethiopian Broadcasting Authority has not allowed religious institutions to own broadcast stations for religious purposes. This research is designed to address the issue of this phenomenon, that is, the religious institutions have not been able to secure the permission to broadcast as per the provisions of the Constitution. Two core points raised on the perception of religious organizations on freedom of expression Article 29 sub article 2 and the broadcasting proclamation No. 533 Article 23/2007. The side of the religious leaders argued that they didn't observe the two articles as adversaries, "though the proclamation seems contradictory to that of the constitutional right given, religion is Parisian and if it is allowed there may be accusing one to the other. Thus, since it is done for the safety of the nation and for the peaceful coexistence of the general public, they didn't oppose the restriction that is similar to the government reasons. While, with significant exceptions of the practitioners in the religious institutions on the other hand; argued that the main objective of religion is to promote positive values to the society, why it is considered as a threat. And they oppose on the blanket prohibition as it is a barrier for the right to the freedom of religious broadcasting.
\end{abstract}

Keywords: Freedom of Expression, Religious Broadcasting, FDRE Constitution, Ethiopian Broadcasting Authority (EBA), Broadcasting Proclamation

\section{Introduction}

In Ethiopia, the legal recognition to the freedom of expression and the press dates back to the 1955 revised constitution. However, this doesn't' not brought any change to the realization of the right of speech, freedom of expression and of the press until the end of the reign of the dictatorial Derg regime. In this regard it is difficult to talk much more about the Media freedom and its law since it didn't proceed from documentation other than its practice. Therefore, we could conclude that it is only after the coming into power of the 1991 transitional government charter that the freedom of the press started to be realized (Mohammed, 2009).

The coming of the new democratic political system brought about the emergence of the new private media in Ethiopia. It is right after the coming to power of the
Ethiopian people's revolutionary democratic front (EPRDF) that the private media mush roomed in to the Ethiopian media scene unlike ever before (Mohammed, 2009:41).

Besides, it is right after the transitional government, the freedom of the press enacted in the proclamation number of No 34/1992, which is the first proclamation ever before. After this press proclamation was brought in to force, the 1995 constitution of the FDRE clearly stated press freedom as a basic democratic right of the people of Ethiopia. And further goes to consider all international agreements that the country signed to be as part and parcel of the law of the land (Ibid:42).

Following the promulgation of the press law, the print media owned by private organizations, religious institutions and by the government began mushrooming. For instance according to the data obtained from the Ministry of 
Information at that time of writing this report, from July 2001 to July 2002 (one Ethiopian fiscal year), a total of 235 print media outlets were registered at the federal ministry of information, of which 205 were private news papers 14 were owned by religions organizations, seven were owned by political organizations and nine were owned by the government (http://www.article19.org:).

Here, political system which could influence political economy of the mass media could be looked at in two perspectives, since; ownership of the mass media could fall either in the hands of the governments or in giant media moguls. For example, media can be monopolized by governments in a dictator ship system of governance and by giant media moguls' in the democratic ones. Because there is no neat divide between commercial and political power.

To this effect, Street J. (2001:104) argued that "in a global economy, the state occupies only a peripheral role, and that what is true for economic policy is also true for communication policy". Similarly, John Downing et al, (1995:161) contends as media policy becomes an important part of the political agenda particularly to the broadcasting which leads to the widespread re- regulation for new commercial operators and public broadcasting. And this is really happened in Ethiopia viewing the three consecutive regimes.

Even though, the new political system has brought to the emergence of many private and religious organizations of print media outlets, it doesn't allow opening a religious broadcast media stations in contrary to the emperor regime. Despite the Ethiopian constitution and the international provisions guaranteed freedom of expression and freedom of the mass media, the Ethiopian religious institutions have been broadcasting their religious programs either from America, Europe or African countries such as South Africa. For instance, the Ethiopian Orthodox church (EOC) which I mostly and nearly knew is broadcasting religions maters from the USA.

Ethiopia, in the post Derg regime, has not only introduced a new constitution but also ratified basic international agreements pertinent to freedom of expression including the Universal Declaration of Human Rights (UDHR), International Covenant on Human Rights, the African charter on human rights and people's rights etc. And at the same time she gave equal recognition to all religions.

With the downfall of the Derg in 1991, and the establishment of a federal republic, the state officially detached from matters of religion and religion also cease to interfere in state affairs. Ethiopian Muslims, Christians and other denominations finally achieved a sense of equality unparalleled in their previous history. The FDRE constitution of 1995 guaranteed equal status to all citizens and to all forms of religious denominations (Berhane, 2009).

Practicing religion like most activities of the social world has rapidly changed and influenced by the rapidly changing information and communication technology of the day.
Today the principal communication tool for connecting people with the world has radically shifted more to electronic media.

The emperor's regime was the time that church (orthodox) and the state were the two faces of the one coin. Besides, freedom of the mass media was not practically guaranteed. Therefore, how could the emperor allow broadcasting for the emerging religion as advocated by the protestant church? If this happened at that time why not now in the time which freedom of expression and the media is guaranteed constitutionally? If this is the logic what is the reason and the rationale behind that hinders the Ethiopian religious institutions to access the broadcast media? What are the perception of the religious institutions towards this and the freedom of expression?

Basically the media (broadcast) is very indispensable for countries like Ethiopia where most of the citizens are influenced by religion and are illiterate that could not use the print media. Besides, incorporation of the forms and structures of this media helps churches to accomplish their main purposes, mainly evangelical and social concern.

Therefore, the critical element of this study is examining and investigating the perceptions of the religious institutions on freedom of expression and the Ethiopian broadcasting proclamation with regard to the relevant international legal frameworks for the freedom of expression and experiences of other countries in relation to religious communication.

\section{Literature Review}

This chapter sets out to explore the basic concept of freedom of expression and the possibilities on its limitations and discusses the theoretical background for this area of study as well as related and pertinent literatures on the issue of freedom of expression. It also deals with some of the major factors that put the broadcast media different over the print in regulating it. It also assesses the role of religion and its media in the public sphere.

\subsection{Highlighting Freedom of Expression}

According to Dennis E. et al, (1984:3) there is a lack of agreement about what is meant by freedom of the press. This is also similar to the freedom of expression since the one can represent the other. Yet, Encyclopedia of International Media and Communication define freedom of the press as follows:

Freedom of the press is a right that is granted to individuals under the law involving the right to receive and transmit information in any medium of mass communication without undue or unreasonable government or other interference (Johnston, 2003:95).

Besides, Freedom of the press and freedom of speech are related though they are not one and the same. There can be distinctions and even contradictions between them. Human Rights Watch for this argues that "Freedom of expression not only protects explicit speech, understandable through words, 
but also symbolic expression, which may consist not only of the artistic expressions. For example the American convention on human rights of its Article 13(1) states which expression is a variety of acts or omissions, whose significance depends on circumstances" (HRW, 1998: xviii).

Similarly, the American Courts from the beginning have held that "what is being protected is words no matter how they are articulated: orally, in a news paper, in a flyer, or in a sign, and in more recent days whether they are sung or broadcast over the airways, contained on a record album or an compact disk, or printed on a button, a T-shirt, or on the back of jacket. Over the years, freedom of speech is substituted by freedom of expression because; man communication is more than words" (Wag Man, 1991:88-89).

\subsection{The Importance of Freedom of Speech}

The concept of freedom of speech is central to realize democracy and implement mass communication. Henceforth, the below listed and detailed ideas constitute the importance of speech freedom. Freedom of speech:

\subsubsection{Is a Prerequisite for the Search of the Truth}

According to John Milton, while defending in religious dogmas, "freedom of expression is as a perquisite for the already discovered truth to thrive and for undiscovered truth to be discovered." He argued that censorship will be "prim eely to the discouragement of all learning, and the stop of truth not only by the dis-exercising and blunting our abilities in what we known already, but by hindering and cropping the discovery that might be yet further made both in religious and civil wisdom" (www.ajolznfb :202)

\subsubsection{Is a Prerequisite for Self-Governance}

Another traditionally influential rational of freedom of expression is the one expounded by A. Meikle John argued on the protection of free speech that is justified since it is a prerequisite for self governance. Proponents of this view claim that democracy, as a system of self governance requires that citizens be well informed of issues of public interest so they could make informed and intelligent decisions taking in to account all available alternatives (Ibid).

\subsubsection{Is a Prerequisite for Personal Development}

As Scanlon concludes, the other line of reasoning that is adopted to justify the protection of speech is one that makes human autonomy, personal development and fulfillment contingent on a person's freedom to express one's self as well as make independent choices of what is right and wrong, what is good taste and bad taste. The argument goes, without such freedom, human being cannot fully develop their personality and be autonomous moral agents with self respect. Therefore, regardless of whether or not freedom of expression helps in the search for truth and in addition to the utility of freedom of expression in facilitating democratic governance, free speech is seen as something that is justified because it makes autonomous personal development and fulfillment possible (Ibid).

Furthermore, in its social context, freedom of speech ensures that citizens have the information they need to participate actively in civic life, and contributes to nonviolent conflict resolution Meikle John (1965), CohenAlmagor, 2001 (www.jou.sagepub.com:237).

\subsection{Broadcast Speech and Why Broadcasters are Treated Differently from other Media}

Almost everywhere in the world there are no refusals of giving licenses to the runners of print media outlets of the private sector. But, there is even in the US in regulating the broadcasting sector unlike the print one. "Under the first amendment to the US constitution it would be unthinkable for the government to try to restrict the number of news papers allowed to exist in one area. But under the new federal communication act, the only people who can start radio station (and now a TV station) are those who have been granted a governmental license" (Wag man, 1991:128).

\begin{abstract}
"The twin concepts of scarcity and economic efficiency are at the heart of the rationale behind government regulation of broadcasting. The electronic spectrum is physically limited. Anybody can buy paper and a printing press, since we can't ran out of either. But there is only a finite No of broadcast frequencies available, and two people cannot broadcast on the same frequency at the same time. Because of this scarcity and the need to impose order, economic efficiency demands that the government in the name of all citizens "own" the electronic spectrum, and parcel it out to private citizens (broadcasters) who act as the public trustees of a frequency" (Wag Man, 1991:128-129).
\end{abstract}

Unlike other modes of expression, radio inherently is not available to all. Because its unique characteristic and that is why, unlike other modes of expression, it is subject to governmental regulation... the right of free speech does not include, however, the right to sue the facilities of radio without a license (Ibid).

In the other dimension, Broadcasting is by far the most important source of information as well as of entertainment, for most people in countries around the world. High level of illiteracy along with difficulty of distributing news papers mean that broadcasting is the only media which is accessible for many people. For the poor, news papers may be prohibitively expensive, and some people simply find it easier and more enjoyable to watch or listen to the news than to read (www.article19.org:1).

As a result of its centrality as a source of information news, and its growing profitability, governments and dominant commercial interests have historically sought to control broadcasting. Frequently, the public broadcaster repartees largely as a mouth piece of government rather than serving the public interest. In many countries, broadcasting was until recently a state monopoly, a situation which still pertains in some states. In other countries, private broadcasting is 
becoming increasingly important and varieties of mechanisms have been used to try to control it. Governments have exerted control through the licensing process while commercial interests have sought to monopolize the broadcasting sector and to focus on low quality but profitable programming (Ibid).

\subsection{Possible Areas for Limitation of Freedom of Expression}

None of the fundamental freedoms, including freedom of expression, is absolute. Of all fundamental freedoms, that of expression is the most elaborated one in international norms and jurisprudence. It may also go to restrictions and/or limitations sometimes it has juridical value in its content. But these limitations and/restrictions must clearly put in all the general international and national bills and laws for better understanding.

Freedom does not simply mean "free from." To be free from everything- free form other people, free from laws, free from morality, free from thought free from emotion is to be nothing (Dennis E et al, 1984:11).

"If expression is considered to possess societal value, it must be considered constitutionally protected unless; it will be conflicted with other laws social values or constitutional guarantees" (Wag man 1991:103).

One can ask if there exists under the 1st amendment the right to speak, can there also be found under the same amendment a constitutionally protected right not to speak? The Supreme Court of the United States has said yes, in situations where none speech is a form of communication (Ibid).

Although there are advocators' who argue against any form of restriction on freedom of expression, under international law, freedom of expression is not absolute and may be subject to restrictions in accordance with law. However any limitations must remain within strictly defined parameters. Article 19(3) of the ICCPR lays down the conditions, which may restriction on freedom of expression, must meet.

The existence of the rights provided in paragraph two of this article carries with it special duties and responsibilities. It may therefore be subject to certain restrictions. But these shall only be such as are provided by law and are necessary:

a) For respect of the rights or reputations of others;

b) For the protection of national security or of public order, public health or morals.

Article 9(2) of the African charter and human and peoples' right also for sees the possibility of restriction, providing: "every individual shall have the right to express and disseminate his opinions within the law." Article 10(2) of the ACHPR also recognizes that freedom of expression may, in certain prescribed circumstances, be limited (www.article19.org: 11).

However, these laws and the international jurisprudence, any restrictions on freedom of expression must meet a strict three-part test. These tests which have been confirmed by these bodies require any restriction on freedom of expression:

a) Shall be prescribed by law

b) Shall be to serve a legitimate aim

c) Shall be necessary in a democratic society to secure the legitimate aim (Ibid).

Meanwhile, this does not mean that national law cannot set aside the international laws for the restrictions of freedom of expression. Countries can set laws of their own environment. But, this law should not be in contrary to the international laws and laws make the protection of freedom of expression in effective. Of course, it is nowhere near this simple. No state, whatever, its constitution, tolerates complete freedom of expression; all states operate codes which provide for restrictions on the content of videos, films, and television programs. What freedom means, and what limits should apply to it, form part of an endlessly evolving political debate (street J, 2001).

\subsection{General Principles for the Right to Freedom of Expression}

Even though states and some commercial maximizing interested groups control the media and freedom of expression, internationally freedom of expression is fully guaranteed under the international principle for freedom of expression.

According to one none governmental organization in British writes on the rights bill of article 19:

Everyone has the right to freedom of expression, which includes the freedom to seek, receive, and impart information and ideas of all kinds, regardless of frontiers, orally, in print, in the form of art, through the broadcast media or through any other media of his or her choice.

This right includes:

1. The right to freedom of expression including both the right of broadcasters to be free of state, political or commercial interference and the right of the public to maximize diversity of information and ideas in broadcasting (www.article19.org:2)

2. Besides, broadcast content should never be subject to prior censorship either by the government or by regulatory bodies. Any sanctions for breach of regulatory rules relating to content should be applied only after the material in question has been broadcast.

However, it is usual to experience not only censoring the content to broadcast or applied to airwave priory before broadcasted but also censoring through refusing to give the license to private investors which is another means of prior censorship.

\subsection{Eligibility of Licensing}

"Strictly enough, there should be no blanket prohibition on a warding broadcasting licenses to applicants based on either their form or nature, except in relation to political parties, where a ban may be legitimate. In particular applicants 
should not be required to have a particular legal form, such as incorporation. Nor should certain type of applicants, such as religious bodies be subject to a blanket ban on receiving licenses. Instead the regulatory body should have the power to make licensing decisions on a cases-by-case basis" (Ibid: 2).

\subsection{Theoretical Framework of the Study}

The theoretical foundation of this study laid down on the perspective of political economy theory of the mass media. Because in one way or another ownership of the mass media can be influenced either by the economic consumption or the political control of governments or commercial interest groups.

As Graham sees on his critique of the political economy of communication, political economy is an area of study that focuses on mass media industry structures, emphasizing the effects of ownership on political systems. For others it is the study of various movements in what might be called the "commodity" cycle in mass media: production, distribution, exchange, and consumption. Still for others, it is only one or two of these moments, the most prominent of those being distribution and consumption (www.philgraham.net)

More elaborately, Graham defines political economy as the study "how the values of all kinds are produced, distributed, exchanged, and consumed (the economic), how power is produced, distributed, exchanged, and exercised (the politics); and how the aspects of the social world are related at any given place and time in history" (Ibid: 2-3).

And as Innis in this similar citation says, obviously, the root of political economy of communication is the concept of 'knowledge monopolies' in which certain privileged groups such as (priests , kings, bureaucrats, soldiers, scientists ) etc have enjoyed a monopoly of access to certain kinds of knowledge in history. By separating communication "content" and technological form, Innis further provides a means for seeing how new media can sustains, erodes, or otherwise transform various kinds of civilizations throughout history based on the types of technologies used to maintain 'knowledge monopolies'.

Contemporarily, Mc. Cheseney in this similar citation also identified two main dimensions in political economy of communication':

First it addresses the nature of the relationship between media communication systems on the one hand and the broader social structure of society on the other hand. In other words, it examines how media and communication systems and content reinforce, challenge or influence the existing class and social relations. It does this with particular interest in how economic factors influence politics and social relations. Second, the political economy of communication looks especially at how ownership, support mechanisms (e.g. advertising) and government policies influence media behavior and content. This line of inquiry emphasizes structural factors and the labor process in the production, distribution, and consumption of communication.

Coming to ownership, the liberalist, revolutionaries and Marxist democracies have their own ideological perspective. For instance, radical libertarian would argue on which the mass media would operate as follows "the media should be free to publish and broadcast what they wish, that sovereign, rational consumers should determine their fate. The government should have no role in the media, except perhaps to foster and encourage their economic success and to referee frequency allocations, as it does in broad casting and cellular communications" (Gross berg et al, 1998:394).

On the other side, a rational Marxist, either of a cultural or political economic stripe, would argue the opposite that media should be created and owned by the public with the state or government saving the necessary function of allocating the means to produce media to the people (Ibid).

Referring to Ethiopia, the incumbent government follows the revolutionary democracy system and the ownership of the mass media are characterized basically by this ideology. As Ministry of information disclosed on a book entitled "The Building Democracy in Ethiopia (translated from the local language Amharic)" it argues "whereas media play a pivotal role in the democratic system, different bodies may be participant in the stakeholder. And government is the main actor of this, particularly in the electronic media. Especially, in developing countries like Ethiopia the other stakeholders have their own limitations. Therefore, government has to participate broadly in the electronic media in a better way than the developed nations. Of course, there is no other option than advancing this to secure the democratization process" (Ministry of Information, 2002:112).

Thus, this indicates that political economy of the mass media is entertained in a manner of the country's ideology and the policy it follows.

\subsection{Libertarian and Social Responsibility Theories: Their Perspectives on Freedom of Expression}

The two theories have similar perspective towards freedom of expression, but they also differ on the way they approach and sense it. "Questions about the proper role and function of media are as old as the media themselves, and systematic approaches to their answers are referred to as formative theory of the media (Gross berg et al, 1998:375)."

From the perspective of libertarian theory freedom of expression is a natural right, a right which man is born with, a right which no one could take away. Under social responsibility however, freedom of expression is grounded on the duty of the individual to his thought, and conscience, it is a moral right. "Freedom of expression is not something which one claims for selfish ends. It is closely bound up with his mental existence and growth thought to claim"(Siebert et al, 1984: 96). 
The libertarian press emerged from the idea that as the public is very capable of accepting or rejecting what is true or false; media should be free from any government intervention. Social responsibility theory on the contrary suggests prescribing the free media what to do and not to do, to the best of the public (Mohammed, 2009). Thus, social responsibility theory is emerged from the short comings of libertarian theory.

\subsection{The Role of Religion and its Media in the Public Sphere}

The role of religion and the religious media can play in the public sphere is still debatable among scholars, theology men and states. Some of them agreed on the wide importance the religious voices and expressions and some of them refuses the religious voices and religious expressions hold in the public sphere. However, from the notion of freedom of expression, any ideas have not to be censored by government rather the expressions have to host many critics for the better exercising of democracy. Religious expressions have also entertained and opened to the public as of other expressions.

In some countries, there is an expectation that religion can be treated as robustly as any other subject, and be just as open to debate as a political issue. In other countries, particularly where there is a State religion or the majority of the population are religiously observant, such debate or critical comment would be considered unacceptable and arouse feelings of serious offence. It is therefore necessary to take these issues into consideration when setting content standards. Freedom of expression has to be balanced against the potential offence to public sensibilities (http://portal.unesco.org:50).

To this effect, David Hollinger in Berhane (2009) argues, religious ideas offered as justifications for public policy should be open to critical debate, and no longer left unchallenged. According to him any religiously motivated public debate should face the pressure and scrutiny of democratic debate.

Lovin in Birhane (2009) briefed that religion can offer insight full critics of the harmful traits of human being, such as materialism, hyper individualism, consumerism and acquisitiveness. Religion can also serve as a means of filling the voids of secular philosophy, (especially at times when the political environment so corrupts), by injecting a number of moral ingredients, such as discipline, generosity, forgiveness, service, hope and endurance. One of the scholars in this camp, Patel calls for active involvement of religion in public life, founded on principles of religious pluralism. He argues religious voices, in all their peculanties have a legitimate and important role to play in public debate.

Patel also argues that when 'liberals' and moderates avoid public discussion of religion and morality, they inevitably create a vacuum to be occupied by extremists; that can take this advantage to obtain disproportionate influence and power (Ibid).
Religious media can play an indispensable role in prompting the moral good values of the society by building ethical behaviors of their follows, in bringing nationality, unity and solidity and articulating pro-democracy demands and even they may struggle for respecting the human right issues, combating malefaction activities such as corruption and political harassments in their country using the responsibility and acceptance they have.

For instance, when the Zimbabwe state sought to more strictly control organized opposition and regime criticism in the 1980's churches were largely able to weather the worst of the pressure and harassment directed at other civil society groups. Media was the case for Christian churches in South Africa under a partied, the exceptional level of public respect for church leaders in societies with large numbers of practicing or supportive members gave Zimbabwean religious leaders a degree of influence and status which Mug Abe regime could not easily ignore or suppress. It is hard, and politically risky to try to destroy the institutional structure or sever international ties of solidarity of organized religions to ban church services and monitor or censor sermon content.

As Chiembu contends in Tomaselli et al (2002:107) contends, Church leaders from many different denominations, particularly Catholics, via the monthly Moto, with a circulation of 27,000 , plays a significant role in articulating pro-democracy demands and providing support for groups seeking political changes). Religious leaders did not have access to state media, nor did they try in any deliberate way to use commercial media for humanitarian or social causes. Hence, Moto was out spoken in its editorial critics of the state on human rights violations, particularly related to alleged Zimbabwean rights violations, particularly related to alleged Zimbabwe national army atrocities against civilians in mutable land in the 1980's, land policy and corruption. Motto also intermittently served as a vehicle for political democratization and system reform proposals of other civil society groups. The fact that it is written in English and has limited, urban based circulation, restricts its impact.

In addition to their evangelical service and social concern however, religious channels interfere in the political agenda of a given nation. For instance, a study held by Cambridge University in the Arab's religious broadcasting shows that as religious channels become political tools to the extent that they promote particular visions of social and political order, such as gender roles, class hierarchies, and thus either preserve or challenge the statuesque. Besides, pressures particularly in religious programs are not simply arguing over the rightness and wrongness of particular ideas but they are also claiming and contesting the authority to speak for Islam (Cambridge University, 2010:6-7).

One clear example is in Egyptian religious channels that the preachers were not directly confronting the state, their popularity and ability to mobilize youth and speak to their concerns but also the state could see them as a political threat (ibid :36). 


\subsection{Historical Background of Religious Broadcasting in Ethiopia}

Despite the fact that currently there is no religious broadcasting in Ethiopia, there was a religious radio during the emperor regime. According to Tamrat (2008) Christian broadcasting in Ethiopia goes back to the establishment of radio voice of the gospel (RVOG) in 1963. RAVOG was to be owned and operated by the LWF, Lutheran churches and missionary societies in North America, Germany and Nordic countries provided financial support. In Ethiopia the name of the radio was literally called "Bisrate Wengel by Orthodox or Yemisrach Dimts Radio by Mekene Eyesus" meaning "voice of good tiding". Except the difference in language the meaning is the same.

According to Siting Lundgren (1983), Shibru (1990), LWFBS; RVOG report (1957-1963) cited in Tamrat (2008: 28), LWF selected Ethiopia to establish RVOG for three main reasons:

First, the project aimed to serve Asia and East Africa; and Ethiopia is a logical direction for the radio project.

Second, in contrast to a rapidly changing situation, Ethiopia at the end of 1950s' seemed a remarkable and stable country than others.

Third, Ethiopia had an old Christian tradition and culture beginning from the $4^{\text {th }}$ century and Christianity had maintained its position as the official religion of the country through/ for centuries. That is why the committee found the risk involved in Ethiopia was still considered smaller than any were else in Africa.

However, the downfall of RVOG followed the collapse of the aged old empire of Ethiopia on the $11^{\text {th }}$ march 1974 when Mengustu Hailemariam's military government nationalized RVOG station by sending its troops to occupy the station (Tamrat, 2008).

\section{Methodology}

This study is designed with the core aim to investigate the perceptions of religious institutions on freedom of expression, and to explore the rationale behind the ownership inaccessibility of the broadcast media to the religious institutions. It looks into what the constitution and the broadcasting proclamation says. This all would be looked at with regard to the international and regional bills of freedom of expression that Ethiopia also ratified and signed as part and parcel of the law of the land.

Therefore, this chapter is designed to the discussion of methodology, the process of data gathering and its techniques, selection of the data sources, and finally how the analysis of the data gathered would be done.

\subsection{Research Design}

In its general sense, the methodology employed in this study is broadly qualitative based on individual in-depth interviews and focus group discussion which are primary sources and primary aims to know the informants views, perceptions on the issues raised in their contexts and experiences.

"Qualitative methodology requires researchers to analyze the topics of their study through sense-making tools that help them understand how people make sense of their experiences" (Richard West et al, 2000: 60). Besides, research studies which are qualitative are designed to discover what can be learned from some experiences of people about an inquiry that researchers also make rhetorical appeal or reasoned argument for their findings.

\subsection{Data Gathering Techniques and Subjects of the Study}

\subsubsection{Subjects of the Study and Sampling}

Currently there are many religious institutions and their denominations registered in Ethiopia. Therefore, out of these many religious institutions and their denominations, only four religious institutions were selected as sample of the study. These are Orthodox, Islam, Catholic, and Mekane EYesus (from the protestant religion) which are cited according to their consecutive history.

The study applied purposive sampling method to select these four religions institutions. Because, as Baxter and Babbie writes (2004:164), purposive sampling is a type of non-probability sampling in which the researcher uses his or her judgment in the selection of sample members based on his or her prior knowledge.

Besides, as is mentioned above there are quite many religious institutions and quite many denominations particularly in the protestant religion. And it is difficult to reach them due to financial and time constraints. Hence, these four religious institutions are selected mainly for tactical reasons. As far as Mekane Eyesus church is concerned, though there are many denominations in the protestant church, the church Mekane Eyesus was member of the RVOG radio of LWF in the emperor region. That is why it is selected from the other ones.

And except, the two later ones, orthodox and Islam has long history and highest number of followers than the other. Therefore, Catholic and Mekane Eyesus are selected based on their fast movement shown and number of followers they comprise in their history than the other unmentioned denominations and they are also entered to Ethiopia long before the unmentioned denominations .

\subsubsection{Data Gathering Techniques}

The researcher undertook individual in-depth interviews with the various religious fathers and media practitioners in the religious institutions that represent the institutions. Similar technique, in-depth interview, is employed with experts and with the Ethiopian broadcasting authority. In addition, the researcher conducted focus groups discussion with Mahibere Kidusan media practitioners of the Ethiopian Orthodox Church, and Yemisrach Dimts radio journalists of Mekane Eyesus church. 


\subsection{In-Depth Interview}

In-depth interviews are very important in the field of research in their effectiveness giving human face to research problems. They are effective for getting people to talk about their personal feelings, opinions, and experiences.

Besides, "In depth-interview typically last between one and three houses. Thus, researchers interested in obtaining rich and thick description than collecting information from hundreds of respondents" (Richard west et al, 2000:65). Further in depth interviews are generally conducted in person that is very preferable.

Similarly, in-depth interview is an important tool in the elaboration of data concerning respondents' feeling and opinion, as well as value. And with its qualitative nature, in depth interview go hand in hand with different data gathering tools (Mohammed, 2009:37).

Hence, unstructured and semi-structured in-depth interview is conducted. Here, un-structured interview helps respondents to give their opinions freely and openly. And unstructured interview will be conducted to strengthen the data will be gathered by focus group discussion. As Deacon et al (1999) points out that semi structured interview gives less concerns for standardization and control and give much space to active and open ended dialogue.

\subsection{Focus Group Discussion}

As David Morgan in Pamela Mykut et al (2004) points out that focus group discussion is purposively important bringing several different perspectives into contact. And the purpose of group interview is to bring several different perspectives into contact about the focus of the inequality in an open and emergent process.

Accordingly, with in this period of time a total of four religious fathers, four media practitioners (one from each religious institution) and media experts and with the broadcasting authority public relation expert are interviewed thoroughly. And two focus group discussions are conducted with Mahibere Kidusan media practitioners of Ethiopian Orthodox Church and Yemisrach Dimts radio journalists of the protestant Mekane Eyesus church as mentioned earlier.

The reason why I could not held focus group discussion in the four religious institutions is first, the two religious institutions namely Islam and the Catholic have not an organized media of their own; second, why I could not gather all of them in one place because they are not voluntary for different reasons.

\section{Results and Discussion}

As highlighted in the previous chapters, this study is aimed to analyze the perceptions of religious institutions on freedom of expression of article 29 (2) and of the broadcasting proclamation number 533's article 23/2007 in focus, particularly from the inaccessibility of the religious organizations to the broadcast media. Thus, this chapter discusses the data collected through individual in-depth interviews and focus group discussion.

\subsection{Constitutional Framework of the Ethiopian Broadcasting Proclamation}

Before 1991, mass media institutions in Ethiopia were under the centralized control of the governments and were reorganized as instruments of propaganda being as a mouth piece of the ideology. This was only abolished following the over throw of the military government. In this regard the following statement strengthened it as follows:

With the coming into power of the new government in May 1991, it appeared that promoting respect for freedom of expression would be prioritized. This was manifested first by the transitional period charter, which provided respect for individual human rights at large and for freedom of expression in particular (http://www.article19.org).

As a result, in 1992, a press law was promulgated which continues to be in force. The press law focuses primarily on the print media leaving the allocation and utilization of radio waves to be determined by law that was promulgated in June 1999 (Ibid).

Following this, freedom of expression has got recognition by the constitution of the Federal Democratic Republic of Ethiopia (FDRE). Hence, the constitution officially declared freedom of expression as democratic right in its article 29.

Article 29 of the FDRE constitution guarantees the right of thought, opinion, freedom of expression and the press in the following terms:

(2) Everyone has the right to freedom of expression without interference. this right shall include freedom to seek and impart information and ideas of all kinds, regardless of frontiers, either orally, in writing or print, in the form of art or through any media of his/her choice.

(3) Freedom of the press and other mass media and freedom of artistic creativity is guaranteed. [...]

(6) Legal limitations can be laid down in order present the well being of the youth, and honor and reputation of individuals $[\ldots]$.

The constitution further provides: All international agreements ratified by Ethiopia are an integral part of the "law of the land," and that "the fundamental rights and freedoms" shall be interpreted in a manner confronting to the principles of the Universal Declarations of Human Rights and International Covenants Human Rights and international instruments adopted by Ethiopia.

Ato Leulseged (Public Relation Officer of EBA), forwarded his idea why the international agreement ratified by Ethiopia sometimes is not applied as follows:

Laws can be laid down limitations for the freedoms guaranteed in constitution if found necessary. And article 29 (6) talks about this. Therefore, there is no contradiction in this perspective. Because, the broadcast media by its 
nature is very reachable at a time and its negative impact is very high. It is not easy to control as of the print one. We can remember the Genocide in Rwanda. The media (broadcast) aggravated the violence and has claimed millions of lives. Therefore, if the government believes that this is necessary for the public order, the reputation of individuals, and the safety of the nation and of the youth, it is possible to lay down limitations on the freedoms protected by the constitution.

All the religious fathers and media practitioners taken for this study agree on the limitation of freedom of expression and of the mass media. However, according one participant of the focus group discussion of the Mekane Eyesus YD (Yemisirach Dimts) radio journalists:

Audiences have the ability to reject a given media before anybody limits it. Freedom of expression has to be with limitation but the audience can exclude one mass media simply by hearing the truth and the contents. For example we know one media in US become out of market recently

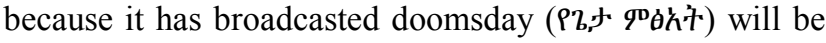
in the next week which is not happened and incredible (Focus group discussion, January 21, 2012).

This idea is similar to that of the libertarian theorists that as the public or audiences are very capable of accepting or rejecting what is true or false; media should be free from any government intervention or any other body. This means no need of restrictions and or limitations since audiences can do this. But the question is do all audiences have the same capability of accepting or rejecting what is true or false? This is very debatable.

AS Aba Hailemarim writes in Yehaymanot Tekamat Dimts

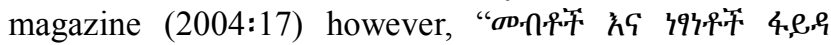

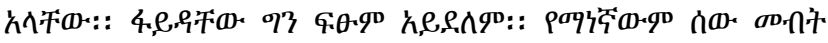

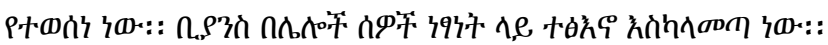

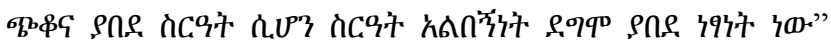
meaning: Rights and freedoms do have purposes. Such purposes, however, are not absolute. Rights do have limitations, too: at least they should not create problem on the freedom of others. Dictatorship/oppression/ is a disordered governance system, and lawlessness is a disordered freedom.

Besides, w/o Rahel Abiy contends as follows:

The restriction seems contradictory to that of the constitutional right, but if it is for the protection of the public order, it is right. When our consciousness develops, I think this will be revised. I believe that media ownership has to be free but this has not to be now on our context. This has to be when our awareness to tolerance has developed. We have to know our audience? Otherwise for whom do we open the owner ship if we do not know our audience (Personal interview, january24, 2012)?

According to her, such limitations are related with the development of human personality of the country and as we do not reach in the level of entertaining such issues the existence of such limitations are indispensable.

\subsection{The Broadcasting Proclamation}

The Ethiopian Broadcasting Agency, now Authority is an autonomous federal regulatory body established according to EBA NO 17811999 now EBA NO 533/2007 with various powers and duties, including to issue, suspend, and revoke broadcasting licenses and with the main objective of ensuring the expansion of high standard, prompt and reliable broad casting service which contributes to the political, social and economical development of the country.

Since, this study is confined and specified to the perception of religious institution on freedom of expression and the broadcasting proclamation; it is going to focus on the broadcast services issuing mainly the religious institutions in accordance with the constitutional guarantee on freedom of expression and to the implication of the religious institutions. But first let's begin with the general of the broad cast proclamation no 533 (2007). The broad casting proclamation in its introduction states like this:

"WHEREAS, broad casting service play a significant role in the political, economical and social development of the country by providing information, education and entertainment programs to the public;

WHEREAS, broadcasting service plays a major role in exercising the basic constitutional rights such as freedom of expression access to information and the right to elect and be elected;

WHEREAS, it is essential to ensure proper and fair utilization of the limited radio wave wealth of the country;

WHEREAS, it has been found essential clearly define the rights and obligations of persons who undertake the broadcasting service;

WHEREAS, to these ends, it has become necessary to revise the existing law on broadcasting services;

These all are the reasons given for the revision of the previous law by the new broadcasting law. Coming to the lists, the proclamation under its article 23 mentioned certain types of bodies not to be issued in the broadcasting service license. In this proclamation eight bodies are not issued in the broadcasting service license while they were three in the previous one.

Religious originations are one of the bodies excluded from getting the issuance of broadcasting service license. The Ethiopian broadcasting proclamation no 533/2007 article 23 lists in the following terms stating:

The following bodies may not be issued with broadcasting service licenses in its English version and the following bodies are not issued with broadcasting service licenses

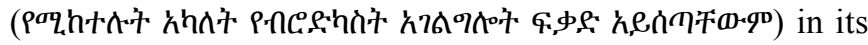
Amharic version which may create some ambiguity. The following bodies are amongst which:

1. A body that is not conferred with a legal personality 
2. Without prejudice to the provisions of other laws regarding foreign nationals of Ethiopian origins, an organization

a) not incorporated in Ethiopia or

b) in which its capital or its management control is held by foreign national

3. An organization of a political organization or of which a political organization is a share holder or a member of a political originations supreme leadership is a share holder or member of its management at any level

4. Religious organizations [...], etc.

Though the authority has visioning to expand, promote diversified, reachable and responsible mass media in the country; because as mentioned in the introduction the broadcasting service plays a significant role in the political, economic and social development of the country by providing information education and entertainment and the broadcasting service plays a major role in exercising the constitutional rights such as freedom of expression and access to information and the right to elect and be elected and because of this it has stood to revise the previous law which is 1999 proclamation, the number of bodies which are excluded from getting the broadcasting service license are increased and this is against their promise and the democratic right written in the constitution.

Besides, it is against the international principles for freedom of expression where blanket ban or prohibition of licensing is unreasonable such as to the religious organizations. And, Ethiopia has ratified and signed these international covenants to be part and parcel of the law of the land. Though they are not binding documents and are not able to restrict countries from having their own domestic laws, they are morally binding. And this is clearly put in the Ethiopian constitution article 13(2). The article describes: "The fundamental rights and freedoms specified in this chapter shall be interpreted in a manner of confronting the principles of the universal declaration of human rights international covenants on human rights and international instruments adopted by Ethiopia."

\subsection{The Need for Broadcast Regulation and Licensing}

There is always a certificate of licensing and regulating the broadcasting media everywhere in the world unlike the print one. In this regard, Overback (2006: 427) discusses on why governments needs to regulate the broadcast media and why licensing is necessary on the rationale of the scarcity of the resource and frequencies stating "only a limited number of frequencies are available and the number of stations that may transmit at one time without causing interference is also limited." He further discusses that such a trend of issuing licenses to broadcasters is a must to secure a proper utilization of frequencies mentioning the licensing experience in the United States; a broadcaster must get a license from the Federal Communication Commission (a broad cast media regulatory body in the country) before going on the air and must renew it periodically."
However, according to Ato Liulseged, in the Ethiopian context, broadcast regulation is seen from the point view of audience coverage and the consequence that will bring in the safety of the general public and the nation. It is not because the spectrum (resource) is scarce. Of course, the broadcast spectrum is limited and that is why the International Telecom Union (ITU) is approving after Ethio-telecom accepts the request of opening a broadcast media. This is because in order not to create interferences in the frequencies/waves. But in the Ethiopian context regulation is made for the purpose of public safety and national security. The resource scarcity is not counted as a main reason for regulating the broadcasting media.

Hayden (2002:8) describes governments has got to use to control the media in the perceived interests of national unity and development. As he further notes, the legacy of the efforts to control the media in the interest of national development continued to influence the media situation in Africa.

However, for Daniel Kibret (Media Expert), the difference of regulating the broadcast and the print is worthless. According to him:

Uprisings or unrests are raised by the existing situation not by the broadcast media. For example, when the Tunisian youth burnt himself, only few people have watched the event but the uprising has reached the whole nation due to the existing situation. Speaking loudly being in the mount of Enteto and broadcasting through radio or $\mathrm{TV}$ is the same if the existing situation is bad. People cannot raise uprisings simply by hearing somebody has burnt himself.

Mahibere kidusan, journalists agree by the presence of a regulatory body that issues, revokes, and suspends the license and controls the process of the media but there has not to be a regulatory body that restricts the ownership of broadcast media. Because restriction by itself creates threat since banning something is a threat. (Focus group discussion, January 17, 2012).

Therefore, it can be said that the need for broadcast regulation and licensing are for many different reasons. Though the reasons are different from country to country; it may be for two reasons mainly for using the scarce and limited resource which is the broadcast to use frequencies in a proper and manageable way and for the protection of public safety and national security. Besides it may be a fear of the broadcast media because it is very influential in reaching very distant area at a time and they want to use for building their power in the name of development and public order. Of course public order is a reason even in the international level. That is why; licensing is taken as a means of regulation for the broad cast media.

Thus, it is possible to conclude that internationally the right of broadcasting is guaranteed for broadcasters for the maximum diversity of ideas and information except it is regulated for the sake of national security, public health, and / moral and due to the limited capability of the resource. 


\subsection{Reasons of Excluding Religious Institutions from Issuing Broadcasting Service License}

Even though banning blanket prohibition of religious organizations is unreasonable in the international principles on freedom of expression, and even the Ethiopian constitution guaranteed freedom of expression to everyone and through any media of his or her choice, the Ethiopian broadcasting proclamation prohibited religious organizations from establishing and running the broadcast media.

Ato Leulseged (Public Relation Officer of (EBA) explained for the reason of excluding the religious institutions is that the difference among the religious organizations on many things. The broadcast media is very reachable in a time for different areas and if the religious organizations could not narrow the difference among them, allowing the broadcast service license is leading the nation into unnecessary situation considering the consciousness level of the people of the nation. And, of course, these things are fulfilled when there will be tolerance, agreements and respecting each other. We did not mention the reasons because a proclamation has to be general when it is declared

Daniel Kibret (Blogger, Author, Editor and Researcher in the Ethiopian Orthodox Church) argues though he is in between of opposing and supporting the restriction:

Ethiopians are religions men. When we read any kind of report released on this issue, it ensures that $90 \%$ of the people are religious and everybody describes himself as a religious man. Therefore, religion has a big role in Ethiopia in all grounds such as politics, economy, social and cultural activities. And it is inevitable participating on these kinds of activities. Developmental attitudes, civilization, etc. excluding religion is impossible. Besides, if there are developments in the freedom of the press in Ethiopia and does not include the religious organizations, it is difficult to say that freedom of expression is fully protected. Because, if we let him you can express your ideas but not in the broadcast media and if religion is the main concern of Ethiopians one can easily conclude that the main concern is discriminated (personal interview January 24, 2012).

Daniel's argument like that of the Declaration of Principles on Freedom of Expression in Africa that it says: "The guarantee of freedom of expression applies with particular force to the media, including the broadcast media and public service broadcasters. Indeed the right to freedom of expression and peoples, right to seek and receive information cannot have a meaningful application unless the media plays its key role in a democratic society in print as well as other media outlets" (http://www.article19.org:8).

But, according to one charitable organization of the UK writes on article 19, the refusals of issuing a license must explained and be reviewed by the judiciary. "Any refusal to issue a license should be accompanied by written reasons and should be subject to judicial review" (www.article 19.org:10).

In this regard, a Commonwealth Expert Group Meeting convened in June, 2002 to develop "Guidelines of Best Practice to Promote Freedom of Expression, Assembly and Association," briefed that "freedom of expression has to be subjected to limitations in the interests of the rights of others and of larger society. However, the need to ensure that the limitations regime is not abused by State authorities is addressed by most of the instruments. Freedom of expression guarantees, therefore, to have put in place "limitations on limitations" (http://www.thecommonwealth.org:10-11).

According Ato Leulseged, the religious exclusion is very similar to that of the political reason. In our sense we have nothing that we have reached in a consensus. For example, in countries like America, South Africa they have reached for many things in a consensus. For instance, in democracy, structure of government nobody can't raise a question. But in our case we haven't reached in consensus to the following things such as federalism, unitary, liberal, social, revolutionary etc which system of government has to be implemented. Therefore permitting the broadcast media having these differences is aggravating the differences rather than narrowing them.

As Andergachew (2007) writes in Tamirat (2008:57), "despite the proclamation did not give detail reason for the prohibition, it seems that the reason for the denied of license to these bodies, particularly to religious and political parties, is the concern that they are partisan and cannot, therefore, use the radio or television out lets to broadcast objectively."

Daniel Kibret on this also argues that it has own its own reason when restricting. Sometimes religion is very sensitive in countries like Ethiopia. Religious issues may be sensitive than the political issues. Therefore, permitting to alleviate the sensitiveness is very critical and we have to differentiate this first. But what is easy is making the organization i.e. the owner to be responsible than searching a responsible body. We have to make a conductive environment for that. And he suggested that the restriction brings three problems:

1 It will make the people not to have opinion that is not founded based on knowledge,

2 It will make the people not understand one to the other because of the lack of enough knowledge,

3 It closes the stage on the national issues for discussion for instance, on the issue of population growth, terrorism, begging etc. from the religious perspectives.

Therefore, this means that media pluralism is very important for many things. It helps ideas, views and opinions to be exercised on from different perspectives and directions. Development is the result of pluralism of ideas and this is very important for developing countries such as Ethiopia.

Likewise, Keane in Street J. (2001:254) argued that people have to be free to follow their conscience and able to test their convictions against their rival claims, thereby strengthening their faith. In the same citation Mill also noted that "knowledge of the world depends upon constant cross examination conventional wisdom. Only with the public demonstration of diversity and difference could ideas flourish and people cultivate their individual character. 
The religious institutions have different reactions and reflections to the constitution and the proclamation, even in interpretation. For instance, Sheik Ahmed Sheik Abdulahi Chelo, the Islamic Affairs Supreme Council president, has totally rejected the permission of broadcast media to the religious institutions. He has expressed his support to the restriction in the following manner:

The permission is unacceptable, we are underdeveloped country and permitting to underdeveloped country like us is like intending to injure yourself. Its negative impact will be worst than its positive impact. Particularly this may be a door for terrorists who have not a religious awareness, who have different aim and want to destabilize the peaceful coexistence of the nation. That is why the permission becomes totally irrelevant and the restriction is as an opportunity for us as an institution. Besides, we believe that the importance of media in spreading religion is not to that much extent. In our case religion has to be expanded through preaching going down to the area and the individual. This has its own value what we call it Hegira. It is not through disseminating the information by the media for instance sitting in your own room (personal interview, January 12, 2012).

Similarly, Ato Abdu Delbar, public relation officer and editor of Hijira magazine of the Ethiopian Islamic Affairs Supreme Council, has supported the restriction. Abdu Delbar in similar stand states that though it is important, broadcast media is very sensitive. Therefore other things taking in to account, if you permit it sometimes they may not talk about religious matter. Even if we all are Ethiopians, it is very dangerous; we can think the Rwanda's case. If there is a lack of consciousness, the problem becomes worse, the consequence can even be worst (personal interview, January 13, 2012).

According to the respondents the handicap for the restriction is not the government's interest to limit freedom of expression rather it is the development of the people's consciousness. Their threat is since the consciousness of the society is less there may be attacking and suing one to the other among the religious institutions and it will badly affect the peaceful coexistence of the society and the country's national security.

Abune Samuel, head of Development and Christian Inter aid Commission in the Orthodox Church on his part says:

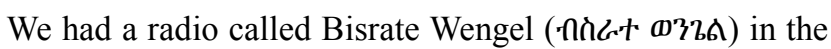
reign of the emperor. And informally we have asked the government to return as a property. But they refused it. And again it comes in proclamation that restricts this. And we did not ask since. Of course you cannot bring an individual and an institution in one manner. If the constitution say everyone, for instance as an individual I am a religious father, I have right to preach but as an institution we have to differentiate from the individual (personal interview, January 17, 2012).
Though they interpreted in this way, for instance Commonwealth Expert Group Meeting convened in June 2002 to develop "Guidelines of Best Practice to Promote Freedom of Expression, Assembly and Association" reviewed in article 19 elaborated in this manner: "The right is guaranteed to "everyone" and not only to "citizens". The right can be invoked, therefore, not only by natural persons but also by juridical persons such as media organizations" (http://www.thecommonwealth.org :10)

Ato Wakshuma, electronic head of Yemisrach Dimts Radio however says:

I don't support the restriction. The reason of the ban may be a fear. The fear is if we open the broadcast media, the majority of the people who cannot read and write can influence us in negative ways. But, we, as a religious media, as Christian how can we influence government in a negative way. Rather we can support the government to build the nation together. Because, the bible says the government is given from God. As a Christian I have to cooperate and appreciate the governments' deeds in our media. Even now using the TWR radio, we are teaching the people to cooperate the government for good works, with the kebele, the localities and in general with the government. We can influence the people positively and work for better. For instance, where is the solution for corruption? The solution is in the bible. We have the source documents and remedies for negative thoughts, illegalities, injustice, crime etc. but the government loses the opportunity to use it (personal interview January 11, 2012).

According to him this means that while the main objective of religion is to promote positive values to the society, why it is considered as a threat? So, it raises a question on the blanket prohibition. Wakshuma further states:

Derg confiscated our radio; similarly, the confiscation was repeated by the restriction, in the present government when it comes in proclamation that does not allow the religious institution investing on the broadcast media. How is it different from that of the Derg? Of course, we are approaching the government to reread, rewrite, emphasize and to rework the law again. Because, our aim is to help the people and the government and we need it to facilitate our day to day activities.

However, Ato Wakshuma further expressed his view in the impact of media and the importance of the media law in the following way:

In fact, I understand and I accept the sensitivity of the media and I accept the importance of media law. If it is not handled in a proper manner, media is more than a weapon which destructs many things in a minute. But, the law should not be in this manner. The present media law should be improved. There should be law, but the law must permit to run in our own line. We know the runners run in their line. If there is no law, the country may be in a chaos. 
Therefore, the patent should have to give with responsibility and limitation. Otherwise, banning is not the solution.

Kes Dereje Jemberu, vice president of Mekene Eyesus church also says, "Once open a time we have raised the question to the government, but the time was not appropriate to host such kinds of questions. Of course, we are the same in all societal activities even though we differ in the dogma of religion. The importance of media is very high. But if it is misused it is very harmful. Therefore, the limitation has to be for these harmful ones not for the good ones. Of course, we understand the government's apprehension since this is very problematic particularly for developing countries, like Ethiopia, which have quite different religions. Therefore, care is necessary. We have to create a conductive environment for it on how we could do; first we have to have regulatory methods by making a council from the government and the religious institutions before allowing" (Personal interview, January 22, 2012).

One can raise the following questions for the different reflections of the leaders and practitioners of the religious institutions. Is it the load or the responsibility and accountability of the religious fathers and the media practitioners carry to the difference of their impression? Is it because the religious fathers have high responsibility and accountability on their institution and they are more concerned to the safety of the nation, welfare of the society, their followers and the institution?

However, this is not only the problem of the government; it is also the problem of the religious institutions' representatives. They don't want to be prophetic life and prophetic voice in religious affairs. They did not push the government to open the door. When did they ask the government? When did they talk about its importance? This indicates that this made the government overlook the issue. For instance, when we see the case of financial institutions, there was only one governmental bank. Investors push the government via their rigorous demand for investment in the sector, and they finally managed to establish and run private banks. We were waiting to opening our account book in governmental bank in a queue, but now we are opening our account books without waiting any line and that is interesting (Mekane Eyesus focus group discussion, January 18, 2012).

In addition, there was a religious radio station in the emperor regime. Is that because we were more conscious and more aware at that time than now? This is very surprising. The law makers are rather less aware that did not know the country background, they believe in fear, griped in fear. Generally, we do not cancel our travel by plane for fear of air crash. The same is true for this. If we do not try to do so, how can we show progress? A patient will be healthy gradually when he begins eating. Therefore we have to formulate a limitation line and use it.

In this line of thought, Glenwood Blank, in his united evangelical action article entitled "Shall the NCC control religious broadcasting?" insisted that the NCC policy was un-
American an un-Christian un-American because it was violated constitutionally generated freedoms of speech and religions, and un-Christian because it would mean that the true Christian faith would no longer be broadcast over radio and television (Schultze, 1990:87).

We have to develop the culture of hosting criticisms against religious issues rather. Of course, there are criticisms against ones religion even in news papers, magazine $C D$, cassette etc, but we treat them. Therefore, cultures of treating criticisms are developed when the media developed. For instance, our foot ball will develop when our media develop (Mekane yesus focus group discussion, January 18, 2012)

Mahibre Kidusan media (focus group discussion) journalists have also the same reflection to that of Mekane yesus one. But they share the fear of others stating like this.

Terrorism is the subject of the day and the broadcast media is easily accessible and reachable at a time that is why people fear especially in Ethiopia where the people have a firm stance in religious matters and the media that will create at violent times is very dangerous. But this is not good solution rather practicing it is the remedy of it. It has to be opened with limitations because fear by itself has its own negative impact.

The following are the methods of limiting according their implication:

$1^{\text {st }}$. The controlling methods that the broadcasting Authority well set out,

$2^{\text {nd. }}$ The religious media editorial policy and,

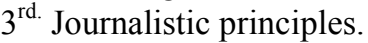

AS the group pointed out, certain limitations were put by the monarchial Ethiopian government with regard to the content and type of programs which originated from RVOG while allowing.

"No program originating from the federation shall;

1. Involve the station in political questions'

2. Constitute an attack on the Ethiopia orthodox church;

3. Constitute an attack upon any organized church, mission or body;

4. Attack or deny the evangelical Christian faith;

5. Contradict generally accepted codes of Christian morality;

6. Involve in commercials advertising" Tamirat (2008:39) writes Siting Lundgren (1983).

Besides the law has to be reread, revised and rectify. Because the time that when the law declared is incompatible with the existing social consciousness. And, indirectly we are transmitting our message from abroad sending our money this is also another big problem we are borrowing money from others and contrary we are sending. What does it mean? It is because the restriction is unconstitutional and a barrier to our right (Mahibere Kidusan, focus group discussion, January 17, 2012).

And it is not expected only to develop in agriculture. Development is multidimensional. Our neighbors can be an exemplary for us. We have to express our ideas through our own choice media without offending others. But when we 
express our ideas it is not expected to be selective. For instance we have to criticize government for a better initiation and we have to transcend the line of the fear, we have to do a lot on this, ownership has to be free but there has to be also a body legally he can issue, revoke, and suspend this.

However, Kahsay gebreziabher, sub-editor of Zenabetekristsian newspaper in the Orthodox Church supports the ban of religious institutions from outlining the broad cast media. Ato Kahsay expressed his support in this manner:

I see the restrictions in positive sides standing from the consciousness that we have in our context. Our consciousness and development to permit is not expected and allowed to do that, because, if it is permitted, there will be people that use this for negative purpose by the cover of the right of freedom of expression and this will enter the country for unremitting war. For instance we are hosting some fundamentalism indicators in the print media. This shows that how much we are under developed in the profession. And broadcast media cannot easily control if aired and we can raise the Rwanda case. The media can be destructive. Therefore the restriction does not limit the freedom of religion but to save from destruction. And that is why I accepted the ban positively. In this case, ownership has to be governmental since there are many religious institutions so, for whom do you permit? It is very difficult (Personal interview, january29, 2012).

But our radio, Bisrat Wengel, ('nhGt क336) and Mekane

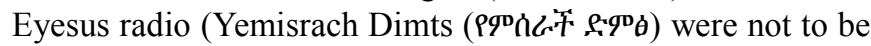
banned from service. Derg confiscated them. And we have been returning our property that the Derg confiscated. Therefore, what is wrong with this? It is like a property. On the other hand why the EPRDF was using Radio Fana? When we asked him his answer is it was even when we were at the jungle and ours' is in the emperor regime. It is immoral. At the same time, though it is restricted here in our country, indirectly others are transmitting their messages from abroad. This is permitting for the rich and prohibiting for the poor. This has to be looked by the government (personal interview January 17, 2012).

Although, the Ethiopian broadcast law does not allow religious organizations to run their own radio station, the production of religious programs in the country is not prohibited for instance, currently YD radio broadcasts social and spiritual programs from abroad in six Ethiopians language languages all programs are produced in Ethiopia and transmitted from South Africa, via trans world radio station (Tamirat, 2008:2).

But, the religious programs are not only transmitting by satellite. Therefore, his response is not right. Besides we are looking instabilities in the Islamic followers and the government is explaining his threat that the instability is began by the users of the overseas media of the Middle East. Therefore, can the government sit silencing his hands and legs looking such kind of instabilities in the country because there is no technology that jams the programs transmits by the satellite? Rather the government has to set the controlling methods.

According Ato Kahsay, exercising right of freedom of expression is a constitutional right. But there is deceiving the right of freedom of expression for unnecessary purpose for example for agitating the mass for violence. We are experienced such kinds of discrepancies here in our case because our background to the profession and for democracy made as not to report the facts and not to tolerate ideas and viewpoints. We had planted a bad plant even in the first press law. Because our people were shouted down their mouse, they were leashed not to express their ideas, not to host different viewpoints for centuries, and if you unleash the shouted mouse it comes with negative consequence and this is happened in the near past. Therefore, we had to limit the freedom and we had to formulate the guide lines for the media.

W/o Rahel Abyi reporter editor of Fikrina Selam newspaper in the Catholic Church also supports the restriction. W/o Rahel in similar stand of ato Kahsay describes like this:

As a religious institution, accessing the broad cast media has its own impact to evangelism where everyone needs evangelism to hear in his room due to globalization impact. But, in our case its restriction is valuable than its permission. Our consciousness has to be developed to some extent in order to permit it. The government has its own reason when he prohibit. He has to protect the safety of the public. And I think he did it. Otherwise there is religious freedom (Personal interview, january24, 2012).

Therefore, it is possible to conclude that The practitioners from the side of Orthodox and Catholic strongly supported the restriction as of the religious fathers stressing restricting is better than allowing as it is made for the safety of the nation and or the peaceful coexistence of citizens.

\subsection{Freedom of Expression in the Perspective of Religion}

Freedom of expression is a fundamental in alienable and inviolable human right which is given naturally simply because, you are human being and it is also a democratic right coming to what you are going to express because what you express could not be offend others' right. Though it is not differentiated from the real world, religious teaching by itself allow everybody to express his/her ideals freely but it also teaches that what you express could not be offend, irritate, and sad others morality. For instance, Abune Samuel elaborates like this:

When you related to the word of God man has to express his feelings freely. And when do you relate this to real world system it is determined by the message what you are transmit. Sometimes someone will be guilty by what he/she has express. But, in religion no one can sue you because of expressing something it may be offensive. But 
when I say this, I don't mean that there is no limitation in the teaching of religion for offensive messages. There is a verse in the gospel that says" meaning: let no arrogance comes from your mouth.

Similarly, the media expert argues like this:

From religious perspective, there is freedom of trying to understand anything you want and trying to tell others whatever you have understand and there is in the bible it

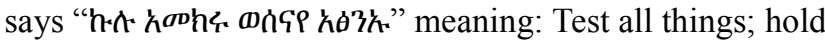
fast what is good. In religion it is the greatest search for truth to understand the different mystery of life and in your search you have freedom of searching whatever way you think is right and the same time you have the right of speaking and responsibility of sharing what even you have under stood from your guest for truth. So, in religion, there is this freedom of knowing and let him others know what you have understood. But, if you tried to see from political point of view, it is mostly related with the governing political party because of some of the expressions or the broadcasted messages challenged the authority of the political party or endanger somehow the life existence of that political party, it will banned. So from the politics point of view, there is normally despise of staying in power. So, there might be very consciousness about what is been expressed (broadcasted) because they related with their own existence (political). So, there is less freedom especially in under developed nations like Ethiopia since there was of political struggle throughout our history. So, the politicians are very cautious about what is to be expressed and what is to be kept hidden or not to be expressed. But if you go to the religious institutions they are not very much concerned in their immediate existence. They are in fact concerned in their religious authority as well but their life is not depend very limited (anonymous personal interview, January 26, 2012).

He also added that fears exist especially, if the religious leaders have good understanding of what is meant by religion or spirituality, they can quest they will be open to accept any ideas from any one and reflect on that to give their ears to different messages opinions and give their ideas to reflect on

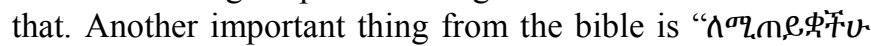

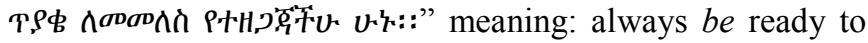
give a defense to everyone who asks you. In principle religious is always ready to listen to any opinions be it negative or positive from all directions. This tells it gives freedom of expression. So, he underlined that there is fundamental difference (anonymous personal interview, January 26, 2012).

W/o Rahel also said that freedom of expression is a human right which is given naturally from God. The right has given for church by God so that believers can express their feelings freely. But what you express whether it is bad or good has its own morality. In religion even though no one can sue the teaching by itself is morally binding.

Though they said there is more freedom to express everything you want in the religion than in the politics there is always condemning if you try to express and take another side or different perspective or something different from the usual one they called him heresies and even they may discriminated you from your social life.

\section{Conclusions}

Ethiopia as a signatory state to the international provisions has recognized and guaranteed the right to freedom of expression in the constitution. It has promised to make the provisions ratified as an integral part of the law of the land and the fundamental rights and freedoms are interpreted in manners of confronting the international agreements. However, the Ethiopian broadcasting proclamation, does not allow religious organizations to have their own broadcast media. And this is not as its vision that the authority aims to bring the diversified and developed broadcast media industry in the country that contributes to the multifaceted development of the nation: economic, political and sociocultural, etc. developments. According the Authority, in the Ethiopian case regulation is made mainly because the negative impact of the media that will bring in the peaceful coexistence of the public in general and the nation in particular. It is not because the resource is limited while the expert says the peaceful coexistence is not polluted because you are broadcasting rather by the existing bad situation.

According to the authority, the reason of excluding the religious organizations from the broadcasting service license is because there are many religious institutions and hence they may lead into unhealthy competition. The reason given is the differences among the religious institutions and the level of consciousness and culture of hosting criticisms on the general public. Hence, since it is done for the safe guard of the society, it ides not contradict with the constitutional right.

With regard to the religious media practitioners some says audiences have the ability to reject a given media before anybody limits it. Freedom of expression has to be with limitation but the audience can exclude one mass media simply by hearing the truth and the contents. Thus, no need of restriction while others said this has to be restricted since it protects the healthy situation of the country learning from the previous bad plant we have planted in the first press law since the consensus of the society in not that much developed to host criticisms due to the bad history we had experienced in our history.

Generally seeing, almost all the religious institutions share the fear of the authority except few journalists in the focus group discussion and one media practitioner. And they do not see the law as a barrier for their right to freedom of expression. However, they underlined in the stance that it has to be opened since there are improvements in the consciousness of the society and the role of the religious media play in solving the societal problems, helping and encouraging, mobilizing the society for development agenda. It is possible to make hand in hand with government for 
national development goal even with better influence than the secular media using the legacy, acceptance, on their followers. However, one religious organization, that is Islam totally rejects the importance of the media and completely agreed by the restriction. But here, there is some differences in interpreting the constitutional right among the respondents for the term "everyone" where it may include the organizations and some difference between the religious fathers and the practitioners in need of the broadcasting.

\section{Acknowledgements}

First and foremost I would like to thank the Almighty God for helping me to complete this study. I would also like to thank my advisor, Gebremedhin Simon (PhD), for his constructive comments and fatherly guidance throughout the work of this research. I owe my special thanks to the religious leaders and the media practitioners and experts who provided me with all the materials and information I needed.

\section{References}

[1] African Media Barometer: The first home grown analyses of the media landscape in Africa. (2010). Fesmedia Africa, Windhoek, Namibia: Published by Friedrich-Ebert-Stiftung (FES) www.fesmedia.org.

[2] Article XIX (2002). Access to Airwaves: Principles on Freedom of Expression and Broadcast Regulation. Internet available at http://www.article19.org/ pdfs/ standards/accessairwaves.pdf

[3] Berhane Zikarge (2009). The scopes and limitations of freedom of religion under the FDRE Constitution: Survey Contemporary Challenges and Problems. AAU: unpublished

[4] Boxter, L,.A., Babbie, E. (2004). The Basics of Communication Research, Canada. Wadsworth Thomson learning Ltd.

[5] Boyd, O. et al (1995). Approaches to Media: A Reader, $1^{\text {st }}$ ed. Oxford University Press Inc.

[6] Deacon, D. et al (1999). Researching Communication: A Practical Guide to Methods in Media and Cultural Analysis. London: Arnold Publication

[7] Downing, J. and Mohammadi, A. (1995). Questioning the Media: A Critical Introduction. $2^{\text {nd }}$ ed. Sage publications

[8] Everethe, E. et al (1984). Basis Issues in Mass Communication: New York, London. Macmillan Publishing Company

[9] Freedom of expression in Ethiopia: the jurisprudential dearth Accessed in 10,10,2011 from (http://www.ajol.info/index)

[10] Freedom of Expression, Assembly and Association Best Practice, available at http://www.thecommonwealth.org/Shared_ASP_Files/Upload edFiles/\%7BE8112AA0-1743-4F8B-BE0 $\overline{\mathrm{F}}$ 53CADB6318AE\%7D_Freedom\%20of\%20Expression.pdf

[11] Grossbeng, L. et al (1998). Media Making: Mass Media in a popular culture. London. New Delhi. Sage Publication Inc
[12] Guidelines for Broadcasting Regulation Accessed on April 5 from http://portal.unesco.org/ci/fr/file download.php/1c9ed59b01d a3180e33cd1b35a5e3908Guidelines+for+Broadcasting+Regul ation.pdf

[13] Human Rights Watch (1998). The Limits of Tolerance: Freedom of Expression and the Public Debate in Chile. New York, Washington, London. Brussles.

[14] Hyden, G. et al (2002). Media and Democracy in Africa, $1^{\text {st }}$ ed. New Brunswick, New Jersey :Transaction Publishers,.

[15] Johnston, D. (2003). Encyclopedia of International Media Communications, Volume 2. New York, USA. Colombia University

[16] Ka Soma, F. (2000). The Press and Multiparty Politics in Africa, University of Tempere.

[17] Maykut, P. and Morehouse, R. (2004). Beginning Qualitative Research: A Philosophic and Practical Guide. $9^{\text {th }}$ ed. Great Britain.

[18] McQuail, D. (2000). Mass Communication Theory. $4^{\text {th }}$ ed. London: Sage Publication.

[19] Media law (2010). Hand book series: http/.www.america.gov.

[20] Media Legislation in Africa: A comparative legal survey Accessed in 10, 10,2011from http://fesmedia.org/fileadmin/filesfesmedia.org/Berger Medi a_Legislation_in_Africa.pdf

[21] Meron Berhane (2006). The Ethiopia Media law with particular reference to the Broadcasting. Proclamation No. 178/1999 AAU: unpublished.

[22] Mohammed Selman.(2009). Editorial Independence in the Ethiopian private media house. AAU, unpublished.

[23] Negarit Gazette: The Constitution of the Federal Democratic Republic of Ethiopia (1995) Addis Ababa, Ethiopia.

[24] Nyamnjoh, B, F. (2005). Africa's Media: Democracy and the Politics of Belonging. Pretoria: UNISA press

[25] Organization for African Unity (OAU). (1986). African Charter on Human and People's Rights (Internet) available at http://www.hrcr.org/docs/Banjul/afrh3.html

[26] Overbeck, W. (1985). Major Principles of Media Law, $2^{\text {nd }}$ ed. CBS College publishing

[27] Political Economy Communication: A Critique. http://www.philgraham/ mme\%20 chapter_final. Pdf 24, 11, 2010 accessed.

[28] Potter, D. (2006). Hand book of independent journalism. US department of state. http/.www.america.gov.

[29] Religious Broadcastiang in the Middle East (2010). Islamic Christian and Jewish Channels: Programmes and Discourages, Cambridge Arab Media Project (AMD) and the prince Alwaleed Bintalal Center of Islamic Studies, University of Cambridge.

[30] Richard,W. Lynn, T. (2000). Introducing communication Theory: Analysis and Application. Mayfiled Publications Company. London. Toronto.

[31] Robertson,G. et al.(2002). Media Law, $4^{\text {th }}$ ed. London: Penguim Books Strand. 
[32] Schultze, Q.(1990). American Evangelicals and the Mass Media. $4^{\text {th }}$ ed. United States: Zondeivan Corporation,.

[33] Siebrt, F. Peterson, T.Schrumm, W. (1984). Four Theories of the press. Chicago. USA: University of Illinois press.

[34] Street, J. (2001). Mass Media, Politics and Democracy: $1^{\text {st }}$ ed. New York: Palgrave publishers limited.

[35] Tamrat, T.(2008). Christian Radio Broad Casting in Ethiopian Changing political context: Case study of Yemisirach Dimts Radio. AAU un published.

[36] The African Commission on Human and Peoples' Rights (2002). Declaration of Principles on Freedom of Expression in Africa. (Internet) available at http:/ www.achpr.org/english/info/charter/en.html

[37] Tomaselli, K. and Dunn, H. (2001). Media, Democracy and Renewal in Southern Africa. $1^{\text {st }}$ ed. International Academic Publishers Ltd.

[38] Tunstal J. and Palmer, M. (1991). Media Moguls, $1^{\text {st }}$ ed. London, New York: Rutledge
[39] United Nations (1948). Universal Declaration of Human Rights Adopted and proclaimed by General assembly Resolution 217 (III) of December 10, 1948 (Internet) available at http://www.un.org/Overview/rights.html

[40] United Nations (1976). International Covenant on Civil and Political Rights United Nations document March 231976 (Internet) available at http://www. hrweb. org/ legal/cpr.html

[41] Wag man, R. (1991). The First Amendment Book, $1^{\text {st }}$ ed. World Almani a print of Pharos Books a Scrips Haward Company.

[42] XIX, Article 19: The legal frame work for freedom of expression in Ethiopia (2002). retrieved from (http.//www.article19.org) in 10,10,2011

[43] XIX, Article 19, Access to Air Waves: Principals on Freedom of Expression and Broadcast Regulation, accessed from www. Article19. Org/date files /standards/access air waves, pdf. 